\title{
$17: 59437839-59433688$
}

National Cancer Institute

\section{Source}

National Cancer Institute. 17:59437839-59433688. NCI Thesaurus. Code C42503.

Physical location of ICAM2_Gene 